\title{
Child Labor, Nutritional Status, and Academic Performance of Filipino Children
}

\author{
Marilyn D. Cardoso \\ Samar State University, \\ Catbalogan City, Philippines
}

\author{
Jojit M. Casiño \\ Department of Education (Samar Division), \\ Catbalogan City, Philippines
}

\begin{abstract}
This study explored the relationships among child labor practices (domestic, fishing/farming, scavenging, and street vending), nutritional status, and academic performance of in-school child laborers in the Province of Samar. Results showed that children who spend more labor hours in street vending derived more income from child labor, had low scores in an attitude towards schooling scale, and had low academic performance. Children who spend more labor hours in domestic activities had better nutritional status and better academic performance. Further investigation along study habits, eating practices, and academic performance of child laborers engaged in the different types of child labor may generate useful findings for possible intervention programs.
\end{abstract}

Keywords: child labor hours, domestic, fishing/farming, street vending, in-school children

\section{Introduction}

Child labor has been considered as an indicator of the prevalence of poverty (Kruger, Soares, \& Bethelon, 2007) and is widespread in most of developing countries (Edmonds, 2008). As estimated by the International Labor Organization (1996), more than 13\% of children aged 10-14 are engaged in child labor; the greatest number of child laborers are in Asia, with 44,600,000 children employed.

Emerson and Souza (2007) posited that child labor can be detrimental - It could hinder the acquisition of formal education and may have some irreparable damage to the health of the child laborers.

In 2003, the effect of child labor on achievement in Ghana was studied by Heady (as cited in Orazem \& Gunnarsson, 2003) and it was revealed that it has substantial effect on reading and mathematics achievement due to exhaustion from work or lack of time spent on assignments.

Moreover, Khanam (2010) said that "There is a trade-off between child labor and schooling". While there are sets of evidence which show that to some extent, income from child labor makes it possible for children to go to school, child labor in general, lowers acquisition of education. Khanam (2010) added that the "Adverse effect of child labor on schooling outcomes is likely to be increased if a child spends more time on labor activities outside the home".

However, there were suggestions that child labor and schooling are not mutually exclusive (Ravallion \& Wodon, 2000). It was revealed in several instances that enrolment rates for working children do not differ significantly in comparison to those who are not in the labor market.

Marilyn D. Cardoso, Ph.D., vice president for academic affairs; professor, College of Education, Samar State University. Jojit M. Casiño, Ph.D., principal, Department of Education (Samar Division). 
Consequently, there may be advantages of child labor, such as vocational training, learning by doing, and the like. Engaging in child labor enables the worker to shoulder the cost of his/her education which could lead to better outcomes later in life. In Brazil, due to four-day school hours (either the entire morning or the entire afternoon) for the formal primary and secondary, there is an opportunity or possibility for a child adolescent to attend school in one period and work in the other (Akabayashi \& Psacharopoulos, 1999). Hence, a child labor ban, according to Doepke and Krueger (2007), "reduces the opportunity cost of sending a child to school".

Mortimer and Johnson (1997) reported that a child can earn valuable human and psychological capital through working while at school, in terms of self-esteem, competence, responsibility, and skills that make $\mathrm{him} / \mathrm{her}$ confident to perform better in school and later in the labor market, hence, adolescent work has some influence on value formation.

In the Philippines, the 2011 Survey on Children conducted by the National Statistics Office (NSO) revealed that out of the 29,019,000 Filipino children aged 5-17 years old, about $18.9 \%$ or 5,590,000 were already working (Tubeza, 2012). Comparing this number to the 2001 survey undertaken by the International Labor Organization and the United States Department of Labor, this registered an increase of about 4,000,000 (Tubeza, 2012).

According to Ericta (as cited in Tubeza, 2012), the majority or $90 \%$ of Filipino child laborers aged 5-9 years old are in school, but by the time they reach 15, only half of them are in school. This is because as the children grow older, they tend to drop out of school for economic and health reasons.

Most of the studies on the effects of child labor on schooling did not consider the nature/type of activities the child laborers undertake to earn and whether their effects on academic performance as well as nutritional status vary. Hence, this study determined the average child labor hours per week that schooling children below 18 years old spend on child labor activities, such as domestic, fishing/farming, scavenging, and street vending. Moreover, it attempted to find out whether child labor is a determinant of school-aged children's nutritional status and academic performance in the Province of Samar, Philippines. Prospective predictors of child labor practices, nutritional status, and academic performance were included, such as age, sex, birth order, parent-respondent's educational attainment, school attendance, average monthly income derived from child labor, attitude towards schooling, and problems encountered.

\section{Objectives}

This study analyzed the relationships among child labor practices, nutritional status, and academic performance of in-school child laborers in the Province of Samar for the school year 2009-2010.

Specifically, this study determined:

1. The profile of the schooling child laborers in the Province of Samar in terms of age, sex, parents' educational qualification, family size, birth order, income earned through child labor, and their nutritional status and academic performance;

2. Child labor practices of the respondents in terms of nature of child labor activities and average child labor hours spent per week in the following activities: domestic, farming/fishing, scavenging, and street vending;

3. Predictors of child labor practices along the four categories of child labor activities;

4. Child laborers' nutritional status and its predictors;

5. Child laborers' academic performance and its predictors. 


\section{Methodology}

This study utilized the descriptive research design using the interview schedule as the main instrument in the collection of data. Only reported cases of child laborers who were in-school during the conduct of this study (school year 2009-2010) were interviewed. Consent from the parents was sought by the researchers with the assurance that confidentiality of information will be observed. Child laborers in this study refer to those who engage in activities that enabled them to earn wages/income. Children working to help their parents in domestic or farm work were excluded in the study.

Municipalities or cities in the Province of Samar with reported cases of child laborers based on the records of the Department of Welfare and Development (DSWD), Samar Provincial Office, were considered as respondent municipalities. Thus, there were 18 municipalities and two cities involved in the study. In the selection of child laborers as respondents, proportionate probability sampling or stratified random sampling of the reported cases was utilized with the municipality or city as the basis of the grouping/stratification. The sample size was computed using Sloven's formula (Pagoso, Cynthia, \& De Leon, 1992, p. 18).

Based on the 2009 records of the DSWD of Samar Province, a total of 2,467 cases of child laborers were reported. Thus, the study consisted of 345 child laborers as samples which comprised $16.15 \%$ (see Appendix for the sampling frame). Out of the 345 samples, only those who were in-school, that is 47 or $13.62 \%$, and their father or mother were interviewed.

Methodological triangulation was utilized in data collection. An interview schedule was prepared and pilot tested at Catarman, Northern Samar, with intra-rater reliability coefficient of 84.60 interpreted as "fairly high, adequate for individual measurements" (Ebel, 1965). Interviews were done to the child laborers and their parents (mother or father) to determine the child labor practices of the school-aged children, their nutritional status, and academic achievement. The child laborers' performance was determined through their grades during the third quarter, taken from the records given by their class adviser. On the other hand, the respondents' nutritional status was measured using the 2007 World Health Organization Child Growth Standards (WHO-CGS) and were categorized as "Normal", "Wasted", "Severely wasted", and "Overweight".

Regression analysis using Statistical Package for the Social Sciences (SPSS) Version 16.0 was utilized to determine the relationships of the variables considered.

\section{Results}

\section{Profile of the Child Laborers}

The typical schooling child laborers in the Province of Samar are more or less 14 years old of age (Mean Age $=14.32$ years with $S D=2.05$ years $)$; male $(N=25$ or $53.19 \%)$ with parents who reached elementary level ( $N=35$ or $74.47 \%$ ); belong to a family of eight members; born as a first child $(N=10$ or $21.28 \%$ ) or second child ( $N=11$ or $23.40 \%$ ), with average monthly income of about $\$ 337.35$ through child labor.

\section{Child Labor Practices of the Respondents}

The respondents were engaged in the following child labor activities: (a) domestic ( $N=23$ or 48.94\%); (b) fishing or farming ( $N=32$ or $68.09 \%)$; (c) scavenging $(N=15$ or $31.91 \%)$; and (d) street vending $(N=17$ or $36.17 \%)$.

Per week, the respondents spend about 9.087 hours $(S D=3.356$ hours $)$ for domestic activities, 9.341 hours ( $S D=2.903$ hours) for farming/fishing activities, 7.820 hours ( $S D=1.740$ hours) for scavenging activities, and 
7.941 hours $(S D=3.211$ hours) for street vending activities.

Moreover, it was revealed that there were respondents who combined two or more child labor activities to earn. Out of 47 respondents, 19 or $40.43 \%$ were engaged in only one type of child labor, 16 or $34.04 \%$ engaged in two types of child labor activities, 11 or $23.40 \%$ were into three types of labor activities, and one or $2.13 \%$ was engaged in all the four types of labor activities.

\section{Predictors of Child Labor by Category}

For the domestic child labor, regression analysis result in Table 1 shows that two variables were found to be significant, namely, sex (highly significant with $p=0.000$ ) and average monthly income derived from child labor (positively correlated and significant with $p=0.030$ ).

Table 1

Regression Analysis Result Between Domestic Child Labor Hours/Week and the Predictor Variables Coefficients ${ }^{a}$

\begin{tabular}{|c|c|c|c|c|c|}
\hline \multirow{2}{*}{ Model } & \multicolumn{2}{|c|}{ Unstandardized coefficients } & \multirow{2}{*}{$\begin{array}{l}\text { Standardized } \\
\text { coefficients } \\
\text { Beta }\end{array}$} & \multirow[t]{2}{*}{$t$} & \multirow{2}{*}{ Sig. } \\
\hline & $B$ & Std. error & & & \\
\hline (Constant) & -40.330 & 46.001 & - & -0.877 & 0.386 \\
\hline Age & -0.064 & 0.300 & 0.026 & 0.215 & 0.831 \\
\hline Sex & -6.162 & 1.207 & -0.604 & -5.107 & 0.000 \\
\hline Birth order & -0.435 & 0.274 & 0.184 & 1.588 & 0.121 \\
\hline Average monthly income derived from child labor & -0.001 & 0.001 & -0.359 & -2.252 & 0.030 \\
\hline Parent-interviewee's educational attainment & -0.843 & 0.827 & -0.123 & -1.019 & 0.315 \\
\hline Third quarter grade & 0.735 & 0.635 & 0.351 & 1.158 & 0.254 \\
\hline Nutritional status & 1.116 & 1.704 & 0.184 & 0.655 & 0.516 \\
\hline School attendance & -1.566 & 1.373 & -0.197 & -1.140 & 0.262 \\
\hline Attitude & -0.064 & 0.106 & -0.085 & -0.606 & 0.548 \\
\hline
\end{tabular}

Note. ${ }^{\text {a }}$ Dependent variable: Domestic.

For fishing and/or farming child labor, regression analysis result in Table 2 shows that about $13.90 \%$ (see adjusted $R^{2}$ ) of the variation in the extent to which the child laborers are engaged in fishing or farming are attributed to the considered predictor variables. However, the $F$ value proved to be not significant $(p=0.096)$.

Similar result was derived for scavenging child labor as shown in Table 2, that is, about $13.90 \%$ (see adjusted $R^{2}$ ) of the variation in the extent to which the child laborers are engaged in scavenging are attributed to the considered predictor variables. However, the $F$ value proved to be not significant $(p=0.097)$.

Table 2

Regression Analysis Result Between Child Labor Hours/Week (Fishing/Farming and Scavenging) and the Predictor Variables

\begin{tabular}{llllllllll}
\hline \multirow{2}{*}{ Model } & \multirow{2}{*}{$R$} & \multirow{2}{*}{$R^{2}$} & \multirow{2}{*}{ Adjusted $R^{2}$} & \multirow{2}{*}{$\begin{array}{l}\text { Std. error of } \\
\text { the estimate }\end{array}$} & \multicolumn{4}{c}{ Change statistics } \\
\cline { 7 - 10 } & & & & & & & \\
Fishing/farming & $0.555^{\mathrm{a}}$ & 0.308 & 0.139 & 4.64454 & 0.308 & 1.827 & 9 & 37 & 0.096 \\
Scavenging & $0.554^{\mathrm{a}}$ & 0.307 & 0.139 & 3.52518 & 0.307 & 1.824 & 9 & 37 & 0.097 \\
\hline
\end{tabular}

Note. ${ }^{a}$ Predictors: (Constant), attitude, sex, age, parent-interviewee's educational attainment, birth order, school attendance, average monthly income derived from child labor, nutritional status, and third quarter grade.

For the street vending child labor, regression analysis result in Table 3 shows that three variables proved to be significant: average monthly income derived from child labor (positively correlated with $p=0.034$ ), third 
quarter grade (negatively correlated with $p=0.034$ ), and attitude towards schooling (negatively correlated with $p=0.012)$. The rest of the variables were found to be not significant $(p>0.05)$.

Table 3

Regression Analysis Result Between Street Vending Child Labor Hours/Week and the Predictor Variables Coefficients $^{a}$

\begin{tabular}{|c|c|c|c|c|c|}
\hline \multirow{2}{*}{ Model } & \multicolumn{2}{|c|}{ Unstandardized coefficients } & \multirow{2}{*}{$\begin{array}{l}\text { Standardized } \\
\text { coefficients } \\
\text { Beta }\end{array}$} & \multirow[t]{2}{*}{$t$} & \multirow[t]{2}{*}{ Sig. } \\
\hline & $B$ & Std. error & & & \\
\hline \multirow{10}{*}{$\begin{array}{l}\text { (Constant) } \\
\text { Age } \\
\text { Sex } \\
\text { Birth order } \\
1 \text { Average monthly income derived from child labor } \\
\text { Parent-interviewee's educational attainment } \\
\text { Third quarter grade } \\
\text { Nutritional status } \\
\text { School attendance } \\
\text { Attitude }\end{array}$} & -69.101 & 41.179 & - & -1.678 & 0.102 \\
\hline & -0.273 & 0.268 & -0.131 & -1.018 & 0.315 \\
\hline & 0.150 & 1.080 & 0.018 & 0.139 & 0.890 \\
\hline & -0.235 & 0.245 & -0.119 & -0.959 & 0.344 \\
\hline & 0.001 & 0.001 & 0.375 & 2.198 & 0.034 \\
\hline & 0.763 & 0.741 & 0.133 & 1.030 & 0.310 \\
\hline & -1.251 & 0.568 & -0.715 & 2.201 & 0.034 \\
\hline & -1.961 & 1.525 & -0.387 & -1.286 & 0.206 \\
\hline & -2.032 & 1.229 & -0.306 & -1.653 & 0.107 \\
\hline & -0.249 & 0.095 & -0.394 & -2.635 & 0.012 \\
\hline
\end{tabular}

Note. ${ }^{\mathrm{a}}$ Dependent variable: Street vending.

\section{Child Laborers' Nutritional Status}

The child laborer respondents are generally of "Normal" nutritional status $(N=27$ or $57.45 \%)$, but a number of them were "Wasted" ( $N=18$ or $38.30 \%)$ and "Severely wasted" $(N=2$ or $4.26 \%)$.

Regression analysis result in Table 4 shows that two variables were significantly correlated with nutritional status, namely, $\operatorname{sex}(p=0.034)$ and respondents' domestic child labor hours per week $(p=0.009)$.

Table 4

Regression Analysis Result Between Respondents' Nutritional status and the Predictor Variables Coefficients ${ }^{a}$

\begin{tabular}{|c|c|c|c|c|c|}
\hline \multirow{2}{*}{ Model } & \multicolumn{2}{|c|}{ Unstandardized coefficients } & \multirow{2}{*}{$\begin{array}{l}\text { Standardized } \\
\text { coefficients } \\
\text { Beta }\end{array}$} & \multirow[t]{2}{*}{$t$} & \multirow{2}{*}{ Sig. } \\
\hline & $B$ & Std. error & & & \\
\hline \multirow{10}{*}{$\begin{array}{l}\text { (Constant) } \\
\text { Age } \\
\text { Sex } \\
\text { Birth order } \\
1 \text { Average monthly income derived from child labor } \\
\text { Parent-interviewee's educational attainment } \\
\text { Domestic } \\
\text { Fishing/farming } \\
\text { Scavenging } \\
\text { Street vending }\end{array}$} & 2.087 & 1.019 & - & 2.048 & 0.048 \\
\hline & 0.018 & 0.060 & 0.044 & 0.300 & 0.766 \\
\hline & 0.650 & 0.295 & 0.386 & 2.205 & 0.034 \\
\hline & -0.048 & 0.055 & -0.122 & -0.864 & 0.393 \\
\hline & 0.000 & 0.000 & -0.346 & -1.873 & 0.069 \\
\hline & 0.098 & 0.151 & 0.086 & 0.646 & 0.522 \\
\hline & 0.083 & 0.030 & 0.503 & 2.770 & 0.009 \\
\hline & 0.002 & 0.030 & 0.011 & 0.063 & 0.950 \\
\hline & -0.023 & 0.033 & -0.105 & -0.700 & 0.488 \\
\hline & 0.015 & 0.040 & 0.076 & 0.371 & 0.713 \\
\hline
\end{tabular}

Note. ${ }^{\text {a }}$ Dependent variable: Nutritional status.

\section{Academic Performance of the Respondents}

In terms of school attendance, about $55.32 \%(N=26)$ of the child laborer respondents expressed that they are "Sometimes" present in class, $31.90 \%(N=15)$ are "Rarely" present, and only $12.80 \%(N=6)$ are "Often" present. 
As regards their academic performance during the third quarter, the highest average grade of the respondents was 84.30 and the lowest was 75.00 ; the mean was 80.31 (below average) with $S D=2.46$.

Regression analysis result in Table 5 shows that four variables were significantly correlated with academic performance: (a) domestic child labor hours (positively correlated with $p=0.030$ ); (b) street vending labor hours (negatively correlated with $p=0.003$ ); (c) nutritional status (positively correlated with $p=0.000$ ); and (d) school attendance (positively correlated with $p=0.000$ ).

Table 5

Regression Analysis Result Between Academic Performance and the Predictor Variables Coefficients ${ }^{a}$

\begin{tabular}{|c|c|c|c|c|c|c|}
\hline \multirow{2}{*}{\multicolumn{2}{|c|}{ Model }} & \multicolumn{2}{|c|}{ Unstandardized coefficients } & \multirow{2}{*}{$\begin{array}{l}\text { Standardized } \\
\text { coefficients } \\
\text { Beta }\end{array}$} & \multirow[t]{2}{*}{$t$} & \multirow[t]{2}{*}{ Sig. } \\
\hline & & $B$ & Std. error & & & \\
\hline \multirow{14}{*}{1} & (Constant) & 67.906 & 2.157 & - & 31.478 & 0.000 \\
\hline & Age & -0.031 & 0.072 & -0.026 & -0.428 & 0.671 \\
\hline & Sex & 0.144 & 0.405 & 0.030 & 0.355 & 0.725 \\
\hline & Birth order & -0.041 & 0.074 & -0.037 & -0.561 & 0.578 \\
\hline & Average monthly income derived from child labor & $7.378 \mathrm{E}-5$ & 0.000 & 0.038 & 0.433 & 0.668 \\
\hline & Parent-interviewee's educational attainment & -0.262 & 0.192 & -0.080 & -1.361 & 0.183 \\
\hline & Domestic & 0.095 & 0.042 & 0.199 & 2.262 & 0.030 \\
\hline & Fishing/farming & 0.055 & 0.038 & 0.112 & 1.453 & 0.156 \\
\hline & Scavenging & 0.067 & 0.041 & 0.104 & 1.626 & 0.114 \\
\hline & Street vending & -0.177 & 0.055 & 0.310 & 3.192 & 0.003 \\
\hline & Attitude & 0.043 & 0.027 & 0.119 & 1.613 & 0.116 \\
\hline & Problems & -0.010 & 0.017 & -0.048 & -0.624 & 0.537 \\
\hline & Nutritional status & 1.819 & 0.278 & 0.628 & 6.555 & 0.000 \\
\hline & School attendance & 1.171 & 0.291 & 0.308 & 4.026 & 0.000 \\
\hline
\end{tabular}

Note. ${ }^{\text {a }}$ Dependent variable: Third quarter grade.

\section{Discussion}

Findings of this study revealed that child labor activities of in-school respondents are not mutually exclusive and that they do not have distinct child labor activities. Most of the time, they combine two or more types of child labor.

Most of the child laborers are into farming or fishing activities inasmuch as these are the types of work that they were trained by their parents to do. This is attributed to the fact that the major livelihood activities in the Province of Samar is fishing/farming. Among the four types/categories of child labor (domestic, fishing/farming, scavenging, and street vending), the female child laborers were observed to spend more labor hours in domestic child labor activities in comparison with their male counterparts which is reflective of the bias towards domestic work which is usually associated with females. This result confirms the 2012 findings of the International Labor Organization that $67.1 \%$ of child domestic workers are girls (International Labor Organization, 2012).

Moreover, children who spend more time in street vending are those who derived more income from child labor and those with low scores in an attitude towards schooling scale. This confirms the statement of Bezerra, Kassouf, and Kuenning (2007) that "Poor school quality and the indifference of families and students to school might cause students to enter earlier into the labor market". 
Significant predictor variables of nutritional status are sex and number of hours spent in domestic work. Generally, male child laborers had normal nutritional status while female child laborers, except those who are engaged in domestic work, are usually categorized as "Wasted" or "Severely wasted".

It is worthwhile noting that those who spend more time in domestic work have better general weighted average in the third quarter grading period, which is contrary for those who spend more time in street vending. Interviews conducted revealed that the employers of children who are into domestic child labor tend to assume the roles of adoptive parents and tend to be more considerate in terms of housework performance of these children which consequently resulted to better academic performance of child laborers.

Moreover, child laborers who have normal nutritional status and those who attend their classes more often have higher general weighted average. This confirms the findings of Abudayya, Shi, Abed, and Holmboe-Ottesen (2009) that diet and nutritional status are positively associated with school performance among adolescents.

\section{Conclusion}

Child labor is generally viewed negatively due to results of numerous studies that engaging in child labor may have short-term or long-term adverse effects on the children's health and school performance. However, the results of this study show that some labor activities-those that are related to housework or domestic - together with good nutritional status and school attendance may prove to have positive effects on the children's academic performance. Figure 1 summarizes the relationships among the variables considered.

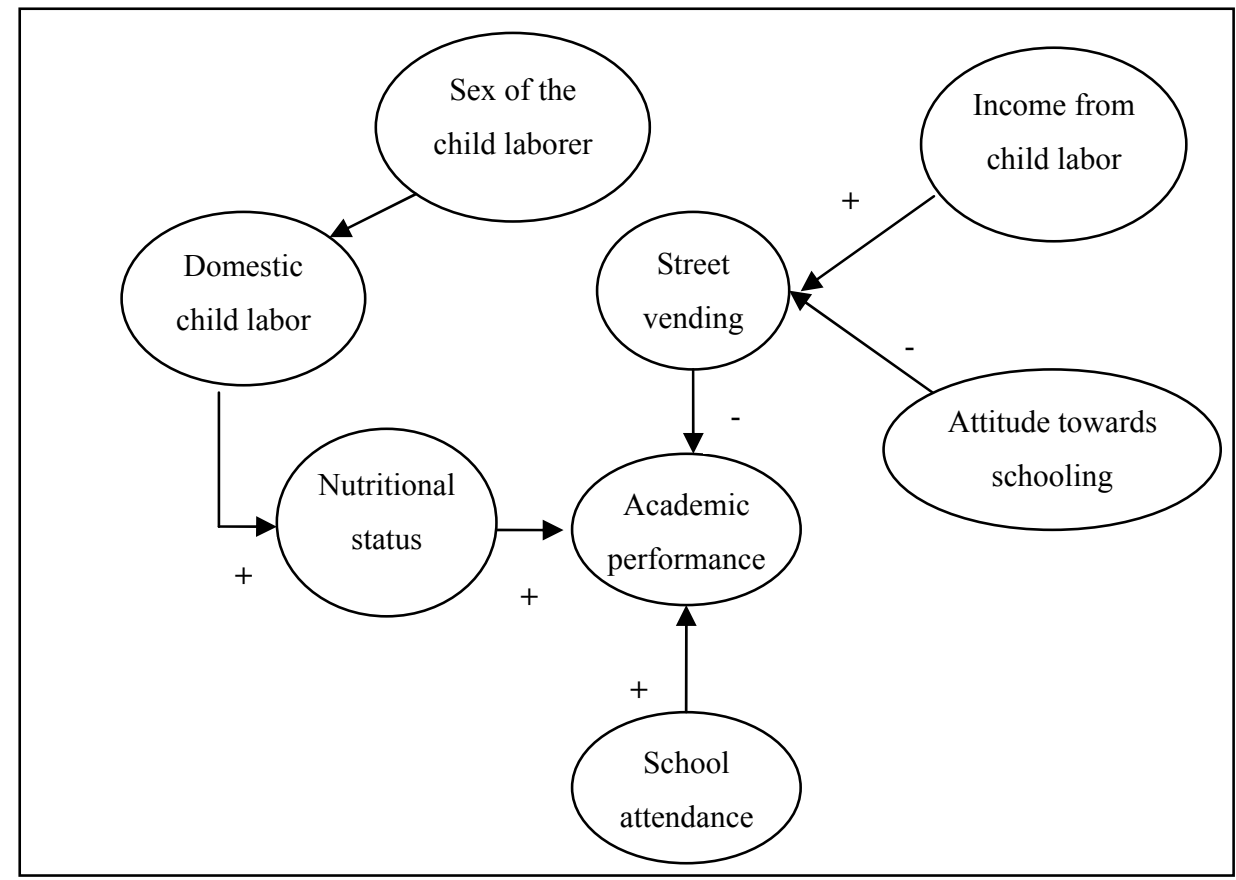

Figure 1. Causal loop among the predictor variables and academic performance of child laborers.

\section{Recommendations}

This study did not look into study habits and eating practices of child laborers in the four categories of child labor activities. Case studies of children who are engaged in domestic child labor maybe undertaken including their study habits and household chores done, to provide a complete understanding of how these 
activities proved to have positive effects on the children's academic performance and may provide useful inputs in proposing possible intervention programs.

\section{References}

Abudayya, A., Shi, Z., Abed, Y., \& Holmboe-Ottesen, G. (2009). Diet, nutritional status and school performance among adolescents in Gaza Strip. Retrieved from http://applications.emro.who.int/emhj/V17/03/17_3_2011_0218_0225.pdf

Akabayashi, H., \& Psacharopoulos, G. (1999). The trade-off between child labor and human capital formation: A Tanzanian case study. Journal of Development Studies, 35, 120-140.

Bezerra, M. G., Kassouf, A., \& Kuenning, M. (2007). The impact of child labor and school quality on academic performance in Brazil. Paper prepared for The Seminar on the Quality of Education in Latin America, Universidad Iberoamericana, Mexico City.

Boadu, K., \& Geyensare, M. (2005). Child labour and its effects on education: A focus on selected fishing communities in Cape Coast Metropolis. Retrieved October 3, 2013, from http://www.scribd.com/doc/55424248/Child-Labour-and-Its-Effects-onEducation

Doepke, M., \& Krueger, D. (2007). Origins and consequences of child labor restrictions: A macroeconomic perspective (Discussion paper from the Institute for the Study of Labor).

Ebel, R. (1965). Encyclopedia of educational research. London: Macmillan Company Ltd..

Edmonds, E. (2008). Child labor. Handbook of Development Economics, 4, 3607-3709.

Emerson, P. M., \& Souza, A. P. (2007). Is child labor harmful? The impact of working earlier in life on adult earnings (Discussion paper from the Institute for the Study of Labor).

International Labor Organization. (1996). Child labour persists around the world: More than 13 percent of children 10-14 are employed. Retrieved from http://www.ilo.org/global/about-the-ilo/newsroom/news/WCMS_008058/lang--en/index.htm

International Labor Organization. (2012). Child labour and domestic work. Retrieved from http://www.ilo.org/ipec/areas/Child domesticlabour/lang--en/index.htm

Khanam, R. (2010). Child labour and schooling in developing countries: A review of the literature. International Journal of Business Research, 10(3).

Kruger, D., Soares, R., \& Bethelon, M. (2007). Household choices of child labor and schooling: A simple model with application to Brazil (Institute for the Study of Labor Discussion Paper No. 2776).

Mortimer, J. T., \& Johnson, M. K. (1997). New perspective on adolescent work and the transition to adulthood. New York, N.Y.: Cambrdige University Press.

Orazem, P. F., \& Gunnarsson, V. (2003). Child labour, school attendance and academic performance: A review (Working Paper of International Labour Office, International Programme on the Elimination of Child Labour (IPEC)).

Pagoso, C. M., Cynthia R. G., \& De Leon, G. (1992). Fundamental statistics. Manila: Sinag-Tala Publishers, Inc..

Ravallion, M., \& Wodon, Q. T. (2000). Does child labour displace schooling? Evidence on behavioural responses to an enrollment subsidy. The Economic Journal, 110(462), 158-175.

Tubeza, P. C. (2012, June 27). 5.59 million child laborers in Philippines, says ILO survey. Philippine Daily Inquirer. 
Appendix: The Sampling Frame for the Child Laborers in Samar

Table A

The Sampling Frame for the Child Laborers in Samar

\begin{tabular}{lcc}
\hline City/Municipality & Reported number of child laborers & Sample size \\
\hline Gandara & 110 & 15 \\
Tarangnan & 117 & 16 \\
Motiong & 119 & 17 \\
Pagsanghan & 105 & 15 \\
Sta. Margarita & 95 & 13 \\
Daram & 301 & 42 \\
San Jose de Buan & 280 & 39 \\
Basey & 115 & 16 \\
Zumarraga & 108 & 15 \\
Paranas & 125 & 18 \\
Catbalogan City & 308 & 43 \\
Calbayog City & 298 & 42 \\
Tagapul-an & 20 & 3 \\
Matuguinao & 122 & 17 \\
San Jorge & 39 & 5 \\
Marabut & 20 & 3 \\
Calbiga & 96 & 13 \\
Talalora & 10 & 1 \\
Pinabacdao & 54 & 8 \\
Jiabong & 25 & 4 \\
Total & 2,467 & 345 \\
\hline
\end{tabular}

